\title{
The Dynamics of Islam in Indonesia in the Perspective of Education
}

\author{
$1^{\text {st }}$ Siti Asiah ${ }^{1}, 2^{\text {nd }}$ Miftahul Huda ${ }^{2}, 3^{\text {rd }}$ Amrin $^{3}, 4^{\text {th }}$ Robby Kharisma ${ }^{4}, 5^{\text {th }}$ Dede Rosyada $^{5}$, \\ $6^{\text {th }}$ Abuddin Nata ${ }^{6}$ \\ \{siti.asiah20@mhs.uinjkt.ac.id ${ }^{1}$, miftahulhuda20@mhs.uinjkt.ac.id², amrin20@mhs.uinjkt.ac.id ${ }^{3}$, \\ robby.kharisma20@mhs.uinjkt.ac.id ${ }^{4}$, dede.rosyada@uinjkt.ac.id ${ }^{5}$, abuddin@uinjkt.ac.id ${ }^{6}$ \}
}

\author{
UIN Syarif Hidayatullah Jakarta ${ }^{1,2,3,4,5,6}$
}

\begin{abstract}
This research aims to find out the transformation of Islamic education in Indonesia is influenced by many factors, including the need to create a nation that is capable, faithful and godly to Allah SWT. the need to improve the quality of human resources in order to compete with other nations, and government policies. This research uses qualitative methods with descriptive analysis. Data collection techniques are carried out by literature studies related to Islamic education in Indonesia. The result of this study is Islamic education in the perspective of history and its transformation from period to period, namely starting from the origin of the establishment of Islamic education, the period of Dutch and Japanese colonization, the post-independence period, and the post-reformation period.
\end{abstract}

Keywords: Transformation; Education; Islam; Indonesian.

\section{Introduction}

The pattern of Islam in Indonesia is very diverse and experiencing dynamics. When viewed from the point of view of religious organizations, there are Islamic styles such as Muhammadiyah, Nahdlatul Ulama, Persis and so on. Viewed from the point of view of Islamic thought, there are Islamic styles that are traditionalist, modernist, liberal, fundamentalist, moderate, conservative, and others.[1] Meanwhile, from the point of view of cultural science, the characters are accommodative, adaptive, and puritanical. Likewise, from the point of view of Islamic education, it is very dynamic. Writing this article does not discuss the dynamics that occur, but will focus on the dynamic aspects of Islamic education. [2]

The dynamics of Islamic education differ in certain periods, starting from the origin of its establishment, Islamic education during the Dutch and Japanese colonial periods, the postindependence period, and the post-reform period. This study looks at Islamic education from a historical perspective and its transformation from period to period.[3]

The philosophy of Islamic education includes giving birth to good, virtuous people, who have the capacity to uphold justice for all people wherever they are. Hasan said, "critical thinking is very important for a Muslim to grow intellectually and spiritually."[4]That is, intellectual growth without spiritual development is aimless wandering, and spiritual development without an intellectual component is meaningless. [5] The author sees that this is inseparable from the different backgrounds that influence it, both scientific, regional, and socio-cultural conditions of each ulema. 


\section{Methodology}

This research uses a qualitative approach with descriptive analysis.[6] Data collection techniques are carried out by literature studies related to Islamic education in Indonesia. In other words, the term Literature Studies is also familiar with the term literature study. Thus, the method used in this paper is the study of literature by focusing on peeling, summarizing and collecting literature, then giving an analysis of the data that has been collected.[7]

\section{Result and Discussion}

\subsection{The Origin of Islamic Education Islamic}

Education in Indonesia has a variety of different backgrounds and different socio-cultural conditions. The various types of Islamic education in terms of history, starting from surau, langgar, rangrang, dayah, pesantren, madrasa, integrated Islamic schools and others. [8]

As an educational institution first and oldest in Indonesia, pesantren is also said to contain the meaning of Islam at once authenticity(indigenous)Indonesia. That is, in the pesantren has been integrated between Islam and Indonesianness. From this we can know that at least the elements of the pesantren consist of three, namely; students, kyai and dormitories. Pesantren is called the father of Islamic educational institutions in Indonesia.[9]

The purpose of establishing a pesantren is partly because of the demands and needs of the times, and also because of the interests of Islamic da'wah, namely in the context of spreading the religion of Islam, as well as creating da'i cadres. The role and gait of pesantren in the history of the Indonesian struggle cannot be underestimated, its contribution is very large in expelling the invaders from the earth of Indonesia. An example is the pesantren founded by the great Indonesian cleric, KH. Hasyim Asy'ari, namely the Tebuireng Islamic Boarding School. This pesantren was established on 26 Rabi'ul Awal 1899 AD.[10] This pesantren was always supervised by the Dutch government. Until now, we still feel the great contribution of Pesantren Tebuireng.

The establishment of the pesantren in historical records began with a kyai who settled (who resided) in one place. Furthermore, students come to seek religious knowledge or study with him. The cost of living and education is provided jointly by the students with the support of the surrounding community. With such conditions, the life of the pesantren is not affected by external economic turmoil.

Almost in line with Dhofier, mentioning that the word pesantren which comes from the root word santri with the prefix "Pe" and the suffix "an" means the residence of the santri. Experts argue that the term santri comes from the Tamil language, which means teacher of the Koran. The portrait of a pesantren is basically a traditional Islamic education dormitory where students live together and study religious sciences under the guidance of a teacher/kyai. The dormitories for these students are located in the pesantren complex where the kyai reside. In addition, there are worship facilities in the form of a mosque. Regarding the question "when and which pesantren was first established? It is described in various pieces of literature that the first Islamic boarding school was founded by Sunan Ampel in Surabaya. As stated by Alfiani, Sunan Ampel with his da'wah related to matters of faith and worship, uses an approach to the community. In the process of developing Islamic education, Sunan Ampel founded a boarding school in 1445.[11] In the literature it is said that Sheikh Maulana Malik Ibrahim is the founder 
of the foundations of Islamic boarding schools in Indonesia, this is because the students after completing their studies at the Islamic boarding school of Sheikh Maulana Malik Ibrahim or who known as Sunan Ampel, he practiced his knowledge by preaching in their respective areas, and made pesantren, following what they had learned from their teachers. Like Pesantren Giri in Gresik, from Pesantren Giri, students from Minang, namely Datuk ri Bandang, brought Islamic civilization to Makassar, other eastern parts of Indonesia.

The description of teaching and education in pesantren in the early days as stated by Noer "a class in these educational centers consists of a group of students who have a striking age difference, who sit around the teacher to receive lessons from the teacher, they form a circle (halakah), no curriculum was announced and all received the same lesson, which was started by learning to read the Qur'an, prayer, faith in Allah (with the intention of avoiding shirk)".14 Furthermore, Nata concluded several things about pesantren, including; Pesantren is a unique educational institution that only exists in Java, because it has historical roots, and traditions, culture, and religion that existed previously in Java. Elements of the pesantren include; the existence of a kyai, mosque, santri, dormitory or hermitage, studying the books. Meanwhile, the religious sciences taught were neuroscience, nahu, fiqh, interpretation, and kalam (tawhid).[12]

\subsection{Islamic Education during the Colonial Period}

During the Dutch colonial period, pesantren had obstacles, because they had to deal with the mission of Christianization in the Indonesian archipelago. Nevertheless, da'wah through pesantren remains the goal of Muslims in Indonesia. Islamic education during the Dutch colonial period experienced a setback when compared to the time when Islam entered the archipelago, where all corners of the region had places to study Islam, such as surau, langgar or other, even Islamic boarding schools. Meanwhile, during the Dutch colonial period, they experienced obstacles because of the Dutch fear of Islam, and they carried the slogans of Gold, Gospel and Glory which became the background of the colonialism and imperialism system. Gold means controlling the wealth of the Indonesian state, with Gospel which has a mission to spread Christianity in Indonesia, and Glory means wanting to control the country of Indonesia and restore the glory of Europe.[13]

Deliar Noer stated that during the penetration of Dutch colonialism and Christian penetration, awareness of Muslims began to emerge to change the way of struggle. Indonesian Muslims began to realize that they would not be able to compete with the challenging forces of the Dutch colonialists, Christian penetration and the struggle for progress if they continued their activities in traditional ways of upholding Islam from the past that had given their friends the ability to do so. their co-religionists in the Middle Ages to overcome the West in science and in expanding their sphere of influence, or by using new methods that had been brought to Indonesia by the colonial powers and the Christian missions.

As explained by Noor as quoted by Daulay that the renewal of Islamic education in Indonesia began with the emergence of the Adabiyah School, this school is equivalent to the HIS school, which teaches religion and the Koran. However, in 1915 this school received a subsidy from the government and changed its name to Hollandsh School Adabiyah.[14]Daulay also cites Steenbrink, the difference between Adabiyah schools and other HIS in Padang lies in the provision of religious subjects two hours per week. Other HIS schools are only open to children of employees and certain families, while Adabiyah schools are open to anyone who can pay tuition fees. Therefore, the Adabiyah School was very popular and liked by the children of traders. However, due to the lack of religious education in this school, and all traditional 
elements were abandoned within a few years, this is unacceptable to the traditional Minangkabau ulama for the rapid changes.20 Along with the establishment of Madrasah Adabiyah, other madrasas emerged in Minangkabau.[15]

Al-Jam'iyat al-Khairiyah, known as Jamiat Khair, was founded in Jakarta on 17 July 1905. This organization is open to any Muslim without discrimination of origin, but the majority of its members are Arabs. In Yogyakarta there is Muhammadiyah, an Islamic social organization, which was founded on November 18, 1912 by Kyai Haji Ahmad Dahlan on the advice of the students and some of his friends, members of Budi Utomo.

The Dutch colonialists made policies that were detrimental to Islamic education. Tilaar, as quoted by Miftah, stated some of these detrimental policies, including; First, limiting the ulama or kyai in teaching Islam, by obtaining permission from the Dutch government in 1925 AD. Second, in 1932 AD, issued a decision to close schools or madrasas that did not have permits. Third, issue a regulation with the name Neutral Religion, which states that the Netherlands is impartial towards any religion by prohibiting religious education in educational institutions or schools. Church schools were turned into government schools and in each Residency, a Christian school was established. This is clearly an effort to hinder the development of Islamic education in Indonesia.[16]

After the Dutch colonial period continued with the Japanese colonial period. During the Japanese colonial period, there was a significant change where the Japanese invaders wanted to win the hearts of the Indonesian people, this was proven by reopening schools that had been closed by the Dutch. Nata explained that although Japan colonized Indonesia more violently than the Netherlands, they still had a soft attitude towards education, especially for Muslims, Muslims (religious leaders) were given the freedom to develop education. This was alleged because Japan's mission was to win the war.[17]

\subsection{Post-Independence Islamic Education}

Development of religious education after Indonesian independence, the government formally gave institutional trust to the Ministry of Religion and the Ministry of Education and Culture. From this, we can see that officially there is dualism in education management in Indonesia. On the other hand, the development of Islamic education is closely related to the role of the Ministry of Religion which was officially established on January 3, 1946. It is stated that one of the tasks of the Ministry of Religion is that the Ministry of Religion provides religious lessons in public and private schools, provides general knowledge in madrasas and holds Religious Teacher Education (PGA) and State Islamic Judge Education (PHIN). Husni Rahim as quoted by Yahya said that at this stage madrasas were not yet seen as part of the National Education System, but were educational institutions under the Minister of Religion.[18]

In 1967, the government opened up opportunities for madrasas to nationalized at all levels, Madrasah Ibtidaiyah Negeri (MIN), Madrasah Tsanawiyah Islam Negeri (MTsIN) and Madrasah Aliyah Islam Negeri (MAAIN). However, this provision only lasts for three years due to limited funds and facilities. Thus, the Decree of the Minister of Religion No. 2131970 is no longer there. The nationalization policy was re-established in 2000.

In 1975, there was a significant change in madrasahs, namely the issuance of a Joint Decree (SKB) of Three Ministers. In this phase, madrasas experience a change in orientation from institutions that concentrate on religious sciences to institutions that concentrate on general knowledge. The limitation on the Three Ministerial Decree is to make religious subjects 
at least $30 \%$ in addition to general subjects. SKB The three ministers are the Minister of Religion, the Minister of Education and Culture and the Minister of Home Affairs.

The Three Ministerial SKB was born based on the Three Ministerial Joint Decree (SKB) No. 6 of 1975 and No. 037/U/1975 concerning Quality Improvement in Madrasah Education. According to the Ministry of Religion, this decree emerged against the background that every Indonesian citizen has the right to have equal opportunities to obtain jobs and a decent living for humanity and teaching. And another thing that strengthens the position of madrasas in the $\mathrm{SKB}$ is that the madrasa certificate has the same value as a public school diploma of the same level, madrasa graduates can continue to public schools at a level above it, madrasa students can move to public schools of the same level and madrasa management and management. The development of religious subjects is carried out by the Minister of Religion, while the guidance and supervision of general subjects at Madrasas are carried out by the Minister of Cultural Education, together with the Minister of Religion and the Minister of Home Affairs. With the Decree of the Three Ministers, madrasas were recognized by the government as part of the National Education System, and on par with other public schools.

Another enlightenment has also begun to appear in Islamic boarding schools. In 1979, a sub-directorate of Islamic boarding schools was created in accordance with the Decree of the Minister of Religion No. 6 of 1979. Thus, the pesantren received official recognition from the government.

With Law no. 22 of 1999/Law No. 32 of 2004 Management of education and culture is handed over to the regions, this is good news for the development of general education because education issues in the regions will be more controlled by the regional government. However, this is not the case for madrasas under the Ministry of Religion, because all affairs related to madrasas are still in the hands of the Ministry of Religion.

Rosyada said that the position of madrasas with Law no. 22 of 1999 concerning Regional Government is less profitable and becomes a very dilemma, because as an educational institution it should be able to be autonomous according to the law. However, unlike madrasahs, these educational institutions are not autonomized, and are not warmly welcomed by local governments. On that basis, the Minister of Religion issued Letter No. MA/402/2000 dated November 21, 2000, which stipulates that the authority to administer religious education in public schools and madrasah administration is delegated to the district/city government which includes operational aspects of implementation, curriculum elaboration, provision of educational staff, provision of facilities and infrastructure, and provision of budget. Meanwhile, other authorities in the field of education as referred to in Government Regulations and Provincial and/or Regency/City Authorities as autonomous regions, as long as they are related to religious and religious education are still the authority of the central government.

\subsection{Islamic Education Post-Reform}

Islamic Educationin this phase is starting to find the bright spot with the government policy through the National Education System Law no. 2 of 2003. If one considers the position of madrasas and Islamic boarding schools as sub-systems of national education, as emphasized by Law no. 2 of 2003 concerning SISDIKNAS clearly shows its role in realizing the goals of National Education, namely creating quality Indonesian people, having faith and piety to God Almighty, virtuous, honest, skilled and responsible. This can be done because in madrasas and Islamic boarding schools, Islamic law subjects are compulsory subjects, such as the Qur'an, hadith, moral creed, fiqh, history of Islamic culture. This subject is the key to fostering the character of students to become quality human beings physically and mentally, in this world 
and the hereafter.And the form of government recognition in Islamic Education Institutions is in Article 17 paragraph 2, namely basic education in the form of elementary schools (SD) and Madrasah Ibtidaiyah (MI) or other equivalent forms as well as Junior High Schools (SMP) and Madrasah Tsanawiyah (MTs), or another equivalent form. Furthermore, Article 18 paragraph 3 states that secondary education is in the form of Senior High School (SMA), Madrasah Aliyah (MA), Vocational High School (SMK), and Vocational Madrasah Aliyah (MAK), or other equivalent forms.33 These are among the articles that affirm the position of Islamic education in the National Education System.[19]

Furthermore, "Islamic education in Indonesia is progressing, progress is seen from the point of view of quantity and quality. There are more and more Islamic educational institutions in Indonesia with excellent facilities and quality. Thanks to the increase in the number of Indonesian Muslim middle class in the last three decades, more and more Islamic philanthropic funds are being used to promote Islamic education. This progress has only occurred in pesantren, which is timeless. [20]

Pesantren which in the "conventional" sense is an institution of traditional Islamic education for tafaqquh fi al din in halakah through learning methods bandongan and sorogan. In its development, the learning method turned into a classical one with more lectures from the teacher or kyai. In contemporary times, learning then also uses the medium of information technology, so that kyai and teachers are no longer the only sources of information and knowledge.[21] Changes or developments in learning methods that involve greater access to information and knowledge have certain consequences. The kyai or guru, and the yellow book are no longer the only sources of knowledge; students can now also gain a lot of knowledge from the virtual world. But, of course, the role of kyai and teacher remains very vital as an example of personality and scholarship. The change in the scientific substance of pesantren is one of the most significant developments since the early 1970s. [22]

Renewal in pesantren institutions today, has been very rapid. Pesantren is an alternative educational institution, not only providing mental, spiritual and noble character, but also providing modern knowledge and skills that enable graduates to be accepted at leading Islamic Universities, both at home and abroad. The domicile of the pesantren is not only in rural areas but also in urban areas. Input from pesantren is now targeting the upper-middle class, who live in urban areas.[23]

Abuddin Nata said that now there are eight kinds of pesantren, namely: (1) Salafiyah Islamic Boarding School which only teaches Islamic religious knowledge as contained in the Yellow Book (tafaqquh fid din); (2) Salafiyah Islamic Boarding School equipped with Madrasah Diniyah; (3) Islamic boarding schools that have been equipped with public school madrasas with Islamic characteristics; (4) Islamic boarding schools that have been equipped with public schools; (5) Islamic boarding schools that have been equipped with Islamic Religious Colleges; (6) Islamic Boarding Schools that have been equipped with General Universities: Polytechnics, Academies, Colleges, Institutes and Universities; (7) Ma'had 'Ali Islamic Boarding School as found in Higher Education; and, (8) Virtual Islamic boarding schools whose students do not stay in one place, but are only based on activities such as pesantren in cities that give birth to urban santri.[24]

A very striking development today is what Azra calls the term "santrinization" of Indonesian Muslim society with the emergence of elite Muslim schools known as "Islamic schools" and recognized by Muslims as "superior schools" or "superior Islamic schools". [25] This is not without reason because the school can be said to be elite from an academic point of view; only the best students can be accepted into the school through a competitive entrance exam. Teachers who meet the requirements are accepted to teach at the school, have much 
better and complete facilities and infrastructure, both from libraries, laboratories, workshops, mosques, sports facilities, and multimedia rooms.[26]

The most competitive elite Islamic schools are SMU Insan Cendekia in Serpong, South Tangerang, Banten,38 and Gorontalo.39 Insan Cendekia High School was founded by a group of Muslim scientists and intellectuals, known as the Agency for the Assessment, Development and Application of Technology (BPPT), which was once led by BJ Habibie. Therefore, it is said that this school has an emotional bond with the Association of Indonesian Muslim Intellectuals (ICMI). It is not surprising that among Muslims, Insan Cendekia High School is known as the "Habibie school".40 other elite schools can also take a look at the schools of alAzhar as the origin of an elite school, who was born in Jakarta, and up to now begin to spread in various cities.[27]

The next interesting thing is the emergence of the trend of integrated Islamic schools. Recently, there has also been the development of Islamic public schools (Islamic Elementary School, Islamic Junior High School and Islamic Senior High School) which are in great demand by upper middle class Muslims who want their children to have academic abilities and a strong Islamic foundation.[28]

In the era Covid-19 Pandemic, Islamic educational institutions have proven themselves to still exist in carrying out learning, both online and offline learning. Even during the Covid-19 Pandemic, compared to other schools, Islamic boarding schools are the foremost educational institutions that carry out offline learning, of course, while observing strict health protocols.[29] All students are tested for Covid-19 before entering the pesantren, and during the learning process no one else is allowed to enter the pesantren. An example of a pesantren that conducts learning directly or outside the network is Pondok Modern Gontor, Ponorogo.

\section{Conclusion}

Islamic education in Indonesia is experiencing endless dynamics and gradual transformation. Islamic education, both madrasas and Islamic boarding schools as Islamic educational institutions in their journey, can adapt to meet the needs of the community in keeping up with the times. To improve the quality of Islamic educational institutions, all elements involved in development must be improved, both in terms of management, curriculum, methods, financing, facilities and infrastructure and so on.

Acknowledgments. Thanks to Allah SWT for the author's permission to complete this article. The author also expresses his gratitude to the academic community of the postgraduate school of the State Islamic University, Syarif Hidayatullah Jakarta, who has funded the publication of articles at ICIIS 2021, especially to the Director of the Graduate School of Syarif Hidayatullah State Islamic University Jakarta, Prof. Dr. Phil. Asep Saepudin Jahar, MA., to the deputy director Dr. Hamka Hasan, MA. for the information in the first ICIIS 2021; to the head of the postgraduate school library at Syarif Hidayatullah State Islamic University, Jakarta, Agus Rifai, Ph. D so that the author can participate in this ICIIS 2021, and thanks to Prof.Dr. Dede Rosyada, MA., and Prof.Dr.Abuddin Nata, MA. as a professor of Islamic education at the postgraduate school of the Syarif Hidayatullah State Islamic University, Jakarta, is a promoter and willing to join in this article. Hopefully this will be useful for work worthy of world reading. 


\section{References}

[1] A. Nata, Education in the perspective of the Quran. 2016.

[2] A. M. Ro'uf, "Contemporary Islamic Thought Paradigm in Understanding Turâth and Modernity," J. Ushuluddin, vol. 26, no. 2, p. 166, 2018, doi: 10.24014/jush.v26i2.4952.

[3] M. A. Abdullah, "Islamic studies in higher education in Indonesia: Challenges, impact and prospects for the world community," Al-Jami'ah, vol. 55, no. 2, pp. 391-426, 2017, doi: 10.14421/ajis.2017.552.391-426.

[4] M. K. H. Al-Asy Ari, "Fiqh Renewal of Gamal Al-Banna and Its Relevance of Fiqh Developments in Indonesia," Millati J. Islam. Stud. Humanit., vol. 2, no. 2, p. 221, 2017, doi: 10.18326/mlt.v2i2.221237.

[5] A. Mundiri, “Organizational Culture Base On Total Quality Management In Islamic Educational Institution,” ADRI Int. J. Islam. Stud. Soc. Sci., vol. 1, no. 1, pp. 1-11, 2017.

[6] H. A. Caner and S. Bayhan, "High-stakes examination policies and transformation of the Turkish education system," Int. J. Educ. Dev., vol. 79, no. July, p. 102263, 2020, doi: 10.1016/j.ijedudev.2020.102263.

[7] Y. Kartabayeva, B. Soltyeva, and A. Beisegulova, "Teaching Religious Studies as an Academic Discipline in Higher Education Institutions of Kazakhstan," Procedia-Soc. Behav. Sci., vol. 214, no. June, pp. 290-296, 2015, doi: 10.1016/j.sbspro.2015.11.648.

[8] M. N. Islam and M. S. Islam, "Islam and democracy: Conflicts and congruence," Religions, vol. 8, no. 6, pp. 1-19, 2017, doi: 10.3390/rel8060104.

[9] T. Aryanti, "Branding the Islamic Village: Modesty and Identity in Yogyakarta Kauman Village, Indonesia," Procedia - Soc. Behav. Sci., vol. 184, no. August 2014, pp. 126-134, 2015, doi: 10.1016/j.sbspro.2015.05.070.

[10] S. Brenner, "Islam And Gender Politics In Late New Order Indonesia," Spirited Polit., pp. 93118, 2019, doi: 10.7591/9781501719486-006.

[11] S. T. Sulistiyono and Y. Rochwulaningsih, "Contest for hegemony: The dynamics of inland and maritime cultures relations in the history of Java island, Indonesia," J. Mar. Isl. Cult., vol. 2, no. 2, pp. 115-127, 2013, doi: 10.1016/j.imic.2013.10.002.

[12] Y. Pribadi, Islam, State and Society in Indonesia. New York: Routledge, 2018.

[13] H. Husni, O. Akhmedov, N. H. Herlina, and ..., "Islam in Russia: History, Challenges, and Future Perspective," ... An Int. J., vol. 8, no. 1, 2020, [Online]. Available: https://www.fsshjournal.org/index.php/jrs/article/view/78.

[14] Ahmad Biglari, "Political Equality and The Issue of Citizenship Rights in Contemporary Islamic Thought," J. Islam. Polit. Stud., vol. 1, no. 2, pp. 77-102, 2019, doi: 10.22081/JIPS.2019.68396.

[15] Shobron; Amrin; and I. M. Rosyadi, "Islamic Education Values in the Tradition of Peta Kapanca of Mbojo Community Tribe in West Nusa Tenggara Department of Islamic Law Universitas Muhammadiyah Surakarta Indonesia Mut122@ums.ac.id," Int. J. Adv. Sci. Technol., vol. 29, no. 5, pp. 6802-6812, 2020.

[16] Huda, Miftahul. (2020). Perkembangan Pendidikan Islam di Indonesia dan Upaya Penguatannya dalam Sistem Pendidikan Nasional. Journal of Islamic Education Research, 1(02), 39-53. https://doi.org/10.35719/jier.v1i02.24.

[17] M. Slama, "Practising Islam through social media in Indonesia," Indones. Malay World, vol. 46, no. 134, pp. 1-4, 2018, doi: 10.1080/13639811.2018.1416798.

[18] R. Shah and M. Lopes Cardozo, "Education and social change in post-conflict and post-disaster Aceh, Indonesia,” Int. J. Educ. Dev., vol. 38, pp. 2-12, 2014, doi: 10.1016/j.ijedudev.2014.06.005.

[19] Firdaus Wajdi, "Globalization and Transnational Islamic Education: The Role of Turkish Muslim Diaspora in Indonesian Islam," J. Adab., vol. 18, no. 2, pp. 176-186, 2018, [Online]. Available: https://doi.org/10.24252/jad.v17i118i2a6.

[20] A. U. Alfauzi and S. Choiriyah, "A character building effort for students in Barokah Nandan Sukoharjo Boarding School through three success programs: Alim faqih, Akhlakul karimah and Mandiri," J. Educ. Manag. Instr., vol. 1, no. 1, pp. 50-61, 2021, doi: 10.22515/jemin.v1i1.3451.

[21] D. Purwati and A. Silvia, "Indonesian learners in Australian education environment: perceptions, 
challenges, and resilience," J. Educ. Manag. Instr., vol. 1, no. 1, pp. 1-8, 2021, doi: 10.22515/jemin.v1i1.3467.

[22] B. Edyar, "Islamic Dynamics in Indonesia," AJIS Acad. J. Islam. Stud., vol. 1, no. 2, pp. 109-130, 2016, [Online]. Available: http://journal.iaincurup.ac.id/index.php/AJIS/article/view/135.

[23] Amrin dan Juryatina, "Students ' interest in Arabic language learning: the roles of teacher," $J$. Educ. Manag. Intruction, vol. 1, no. 1, pp. 40-49, 2021.

[24] M. A. Prof. Dr. H. Abuddin Nata, The Policy of Islamic Education and General Educational In Indonesia. Depok: PT. RajaGrafindo Persada, 2021.

[25] Z. H. Lubis, "The Dynamics of Contemporary Islamic Thinking and The Role of Education: Islamic Fundamentalism, Opponents, and Hybrid Thought," Al-Tahrir J. Pemikir. Islam, vol. 21, no. 1, pp. 105-133, 2021, [Online]. Available: https://doi.org/10.21154/ALTAHRIR.V21I1.2560.

[26] M. Jaschok and H. M. V. Chan, "Education, gender and Islam in China: The place of religious education in challenging and sustaining 'undisputed traditions' among Chinese Muslim women," Int. J. Educ. Dev., vol. 29, no. 5, pp. 487-494, 2009, doi: 10.1016/j.ijedudev.2009.04.004.

[27] Abdul Najib, "Patterns of Islamic Education Moderation in Indonesian History," Didakt. Relig., vol. 6, no. 1, pp. 107-124, 2018, [Online]. Available: https://doi.org/10.30762/didaktika.v6i1.1097.

[28] Supriyanto, "Religion and State in the Perspective of Islamic Thought," Mawa'Izh J. Dakwah Dan Pengemb. Sos. Kemanus., vol. 11, no. 2, pp. 1-13, 2020, doi: 10.32923/maw.v11i2.1469.

[29] A. A. Wardani and T. Suharto, "Optimizing the role of informal learning in the perspective of Islamic education during the Covid-19 pandemic," J. Educ. ..., vol. 1, no. 1, pp. 28-39, 2021, [Online]. Available: http://ejournal.iainsurakarta.ac.id/index.php/jemin/article/view/3456. 